\title{
Genetic differentiation of dengue vector Aedes aegypti in the small geographical scale of Banyumas District, Indonesia based on Cytochrome Oxidase I
}

\author{
MOHAMMED A. MOHAMMED ${ }^{1,2}$, AGUS NURYANTO ${ }^{1}$, ENDANG SRIMURNI KUSMINTARSIH ${ }^{1, \vee}$ \\ ${ }^{1}$ Faculty of Biology, Universitas Jenderal Soedirman. J1. Dr. Suparno No. 63, Purwokerto Utara, Banyumas 53122, Central Java, Indonesia. \\ Tel.: +62-281-638794, Fax. +62-281-631700, `email: endang.kusmintarsih@unsoed.ac.id \\ ${ }^{2}$ Department of Biological Science, Al-Fasher University. Al-Fasher, Sudan
}

Manuscript received: 27 February 2020. Revision accepted: 11 January 2021

\begin{abstract}
Mohammed MA, Nuryanto A, Kusmintarsih ES. 2021. Genetic differentiation of dengue vector Aedes aegypti in the small geographical scale of Banyumas District, Indonesia based on Cytochrome Oxidase I. Biodiversitas 22: 675-683. Aedes aegypti (Linnaeus, 1762) is a major vector of arboviruses. Currently, Ae. aegypti is spreading throughout the Banyumas District, Central Java, Indonesia and there is little information regarding the genetic variation of this species, yet the information is essential to develop effective vector control measures. The aims of this study was to evaluate the genetic differentiation of Ae. aegypti populations in South Purwokerto and Cilongok subdistricts. Mosquito larvae were collected using oviposition traps inside houses in South Purwokerto and Cilongok (Jastaba village). Twenty larvae of Ae. aegypti, ten from each location were identified and used for genetic analysis. Analysis of mitochondrial cytochrome Oxidase I (mtCOI) produced around $600 \mathrm{bp}$ fragments, detecting ten haplotypes. The haplotype diversity and nucleotide diversity indices were higher in South Purwokerto samples. Tajima and Fu's statistics indicated that the sampled populations were in genetic equilibrium. Indices of demographic history were fit for a spatial expansion model. Higher genetic variation was observed within the population compared to between the populations. Furthermore, strong genetic difference was detected between the two populations, with highly significant $F_{S}(p<0.0001)$. Weak haplotype sharing occurred between the two populations assuming that the gene flow was facilitated by human transportation. All haplotypes were a cluster of single clades and closely related to haplotypes generated from previous studies in Central Java.
\end{abstract}

Keywords: Aedes aegypti, Banyumas, cytochrome oxidase I, genetic diversity

\section{INTRODUCTION}

Aedes aegypti (Linnaeus,1762) is the primary vector responsible for transmitting the dengue virus and other arboviruses (Black et al. 2002; Brady et al. 2012). According to World Health of Organization (2019), around 3.9 billion people in 128 countries are at risk of dengue infection with approximately 390 million per year. Indonesia is one of countries that has been experiencing an incidence of arbovirus diseases (Yoshikawa and Kusriastuti 2013). Currently, dengue virus is being spread in almost all Indonesian provinces. For example, Götz et al. (2016) and Wijayanti et al. (2016) described dengue disease incidence in the Java region. A molecular epidemiological survey in Banyumas District has revealed multiple dengue serotypes (Kusmintarsih et al. 2018). Banyumas District is one of the endemic areas of dengue hemorrhagic fever (DHF) in Central Java. According to Banyumas District Health Office (2020), around 16 villages in 2018 and up 50 villages in 2019 were affected by dengue disease.

Elimination of breeding sites is most effective way for control of Ae. aegypti vector (Nathan 1993), in addition to the traditional methods of fogging and using house insecticide, to prevent dengue virus (Vontas et al. 2012). Although insecticide fogging may reduce the density of adult mosquito population, it has little effect on the larval breeding sites. Insecticide treatment could reduce mosquito population size, speed up genetic bottleneck and accelerate genetic drift (Twerdochlib et al. 2012). The long-term use of insecticide has caused resistance against a variety of insecticides (Moyes et al. 2017).

Several molecular markers, such as Cytochrome Oxidase I and Restriction Fragment Length Polymorphism (RFLP) have been used to study genetic diversity among Ae. aegypti population (Scarpassa et al. 2008; Sharma et al. 2013) revealing that different factors such as environmental, urbanization, and human activities impact the genetic structure of vector species (Huber et al. 2002). Studies of genetic variations in Ae. aegypti population needs DNA markers that display a fast-evolving gene, so that the evolution and relationship among the vector species can be detected (Beebe et al. 2005). Mitochondrial DNA is more powerful than nuclear DNA for population genetic studies, so far, it encodes a gene with a high rate of evolution and rarely undergoes recombination (Avise et al. 1987; Beebe et al. 2005). In particular, mitochondrial Cytochrome oxidase I (mtCOI), is a powerful tool for assessing Ae. aegypti genetic studies (Anoopkumar et al. 2019). Cytochrome oxidase I has been used in population genetic studies of Ae. aegypti in different geographic regions (da Silva et al. 2012; Paupy et al. 2012; Seixas et al. 2013; Gandhi et al. 2020). In Banyumas District, 
information about the genetic variation of Ae. aegypti is not yet available, so studies on genetic diversity and gene flow patterns are essential for dengue vector control. For instance, gene flow information is useful for identifying the level of insecticide-resistant gene dispersal (Rasheed et al. 2013).

Although no information about the population structure of Ae. aegypti is available in Banyumas District, Central Java; one exception is the study reported by Yohan et al. (2018), which analyzed small samples of Ae. aegypti from the north coast of Central Java and concluded that the species exhibited considerable genetic diversity. This preliminary survey was aimed to assess the level of genetic differentiation and gene flow of Ae. aegypti population in the small geographic scale of South Purwokerto and Cilongok in Banyumas District by analyzing mitochondrial Cytochrome oxidase I.

\section{MATERIALS AND METHODS}

\section{Description of the study area}

Banyumas District (7.4832 S, 109.1404 E) is located in the southwest of Central Java Province, Indonesia (Figure 1 ), with a total area of $132,760 \mathrm{~km}^{2}$, and 1.85 million people inhabit the region. Banyumas District consists of 27 sub-districts with a total of 331 villages.
A tropical monsoon climate distinguishes the climate in Banyumas. Purwokerto, the capital city of Banyumas lays $55 \mathrm{~m}$ above sea level and covers around $38.58 \mathrm{~km}^{2}$. Cilongok is the largest sub-district in Banyumas District, lays $209 \mathrm{~m}$ asl. and covers an area of $105,34 \mathrm{~km}^{2}$ (Central Bureau of Statistics 2017). According to the Indonesian Meteorological, Climatological, and Geographical Agency (2020), the average temperature in South Purwokerto is approximately $26.9^{\circ} \mathrm{C}$, and about $2284 \mathrm{~mm}$ of precipitation falls annually. While in Cilongok, an average annual rainfall of $3669 \mathrm{~mm}$ and an average annual temperature of $25.8^{\circ} \mathrm{C}$.

\section{Research samples}

Mosquito larvae were collected using oviposition traps (ovitraps) from houses in South Purwokerto and Cilongok (Jastaba Village) in the period from April to August 2019. Ovitraps are small pots filled with tap water to allow the female Aedes species mosquitoes to lay their eggs (Fay and Perry 1965). Along with study, 25 ovitraps were placed inside three houses in Cilongok and four houses in South Purwokerto for two to three weeks. Ovitraps were transferred to laboratory, and larvae reared at room temperature to third instar. Ae. aegypti larvae were identified based on a described morphological key (Stojanovich 1965). Around 20 larvae of Ae. aegypti were clearly identified and used in molecular analysis Table 1.

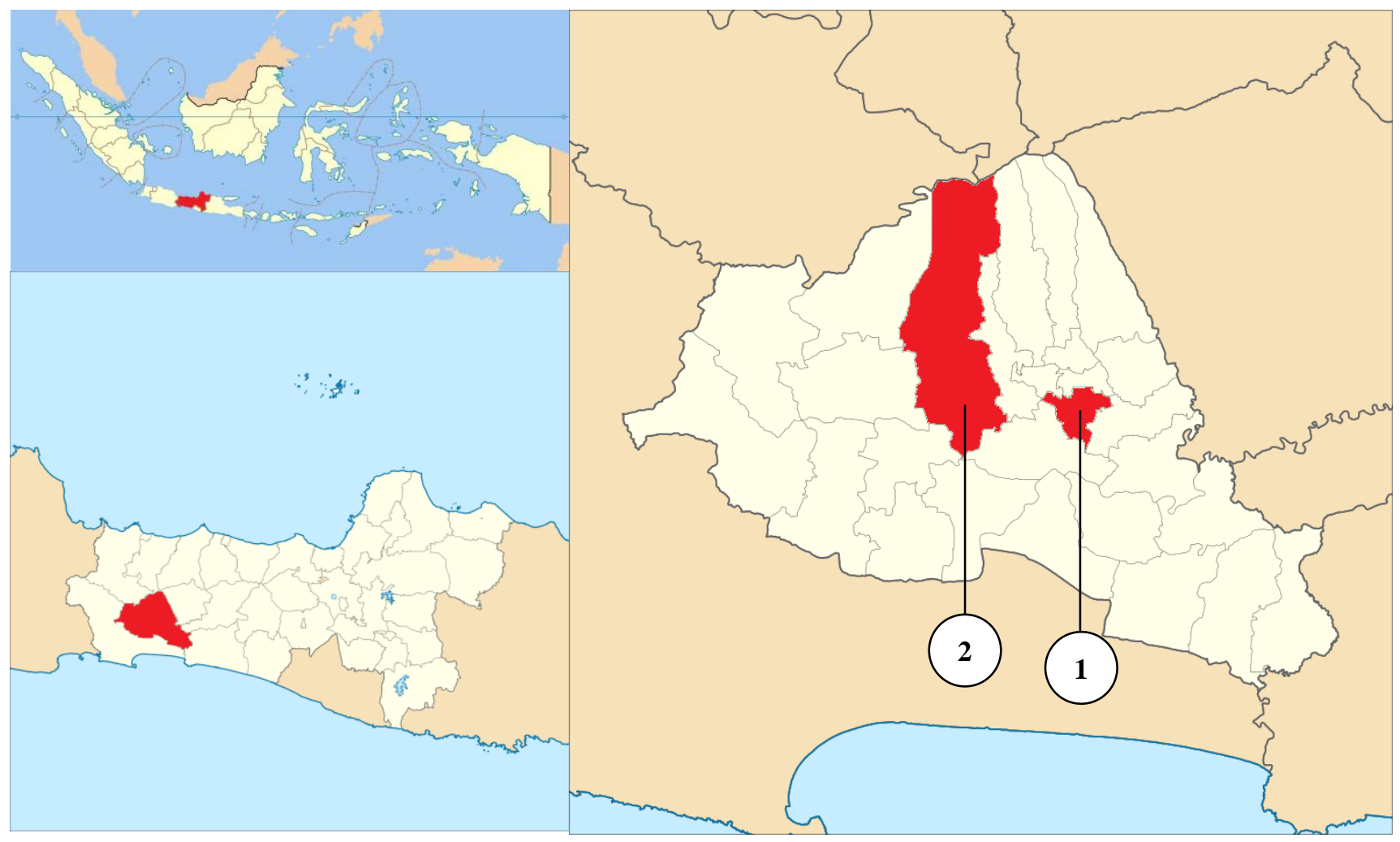

Figure 1. Map showing sampling sites in Banyumas District, Central Java, Indonesia. 1. South Purwokerto and 2. Cilongok 


\section{DNA extraction, COI amplification and sequencing}

Individual larvae were placed in a $1.5 \mathrm{ml}$ tube, and DNA was extracted using genomic DNA extraction mini kit-tissue (Geneaid) as prescribed by the manufacturer instructions. The COI gene was amplified using the forward primer 5-TAGTTCCTTTAATATTAGGAGC-3 and the reverse primer 5-TAATATAGCATAAATTAT TCC-3) generating around $600 \mathrm{bp}$ fragment (Beebe et al. 2005). PCR amplification was performed by a thermal cycler (Primus $25^{\circledR}$ advanced-PEQLAB) using Go-Taq Green Master Mix (Promega) mixture contained with $50 \mu \mathrm{l}$ of (Go-Taq Polymerase, dNTPs, $\mathrm{MgCl}_{2}$ ), $0.4 \mathrm{uM}$ of each primer and 50-100ng of DNA template. The cycling consisted of initial denaturation step at $95^{\circ} \mathrm{C}$ for 2 minutes, 40 cycles of $95^{\circ} \mathrm{C}$ for 30 seconds, $50^{\circ} \mathrm{C}$ for 1 minute and $72^{\circ} \mathrm{C}$ for 1.5 minutes with a final step at $72^{\circ} \mathrm{C}$ for 10 minutes and storage at $4^{\circ} \mathrm{C}$. The fragments were separated by $1 \%$ agarose gel electrophoresis and visualized by staining with ethidium bromide (Borst 2005). A $40 \mathrm{uL}$ of PCR unpurified product from each sample was sent to $1^{\text {st }}$ base DNA sequencing service.

The COI haplotypes and genetic differentiation analysis

Twenty nucleotide sequences were assembled using Bio-Edit, and multiple sequence alignment was done with ClustalW using MEGA X (Kumar et al. 2018). The sequences' similarity for fragments generated in this study was compared in the GenBank database using a Blastn search. Accession numbers were obtained after all sequences generated in this study were submitted to GenBank (Table 1).

The nucleotide sequence for both populations was analyzed by DNAsp.v6 software (Rozas et al. 2017). The basic sequences' statistics measured were haplotype diversity $\mathrm{Hd}$, nucleotide diversity $\pi$, number of polymorphic sites $S$, and the average number of nucleotide differences $k$. The Tajima neutrality test $(D)$ (Tajima 1989) and the $\mathrm{Fu}$ test ( $\mathrm{Fu}$ 1997), which give information on selective neutrality in populations, were computed in DNAsp.v6. The examination of deviation from neutrality by both statistics was based on 1000 coalescent simulations.

The hypothesis of the expansion model was measured based on pairwise nucleotide differences between haplotypes were compared to the expected frequency distribution to test the effect of population growth or mismatch distribution (Roger and Harpending 1992; Harpending 1994). Estimations of raggedness index R and sum square deviation (SSD) were computed in Arlequin ver.3.5 (Excoffier and Lischer 2010) with 1000 replicates of parametric bootstrapping to estimate deviation from the expansion model. Other parameters measured were the time of expansion $(\tau)$, which was estimated with $95 \%$ confidence intervals (CI), the mutation parameters, (theta initial $\theta_{0}$ and theta final $\theta_{1}$ ), and the number of migrants $M$ (Hamilton et al. 2003; Excoffier 2004).

Genetic differentiation analysis was estimated based on the Fixation Index $\left(F_{S T}\right)$ and hierarchical analysis to estimate genetic differentiation within and among the population. This is based on Analysis of Molecular Variance AMOVA (Excoffier et al. 1992) using Arlequin (Excoffier et al. 2010). Median-Joining haplotype network was constructed using a network software (2004-2019 Fluxus Technology Ltd) to evaluate the relationships between haplotypes. Partial sequences (forward) obtained in this study were used to build phylogenetic tree using neighbor-joining (NJ) method in Mega X software. Trees were inferred with the Tamura 3-parameters model by 1000 replicates bootstrapping. To estimate level of phylogenetic relationship with Ae.aegypti from other regions, partial cytochrome oxidase I sequence from Indonesia (KP334267.1, KP334266.1, KP334268.1 and KP334269.1), Pacific region (KT313650), Panama (KX171394), and Ae. albopictus (GenBank: KP334275.1) as outgroup were retrieved from GenBank and used to construct a phylogenetic tree.

Table 1. Sampling information and accession number of each Ae. aegypti sample

\begin{tabular}{llccc}
\hline Sample code & \multicolumn{1}{c}{ Sampling site } & Coordinates & No. of Larvae & GenBank accession No. \\
\hline PWT10 & South Purwokerto, Banyumas District & 7.4243 S 109.2396 E & 1 & MT881571 \\
PWT8 & South Purwokerto, Banyumas District & 7.4243 S 109.2396 E & 1 & MT881572 \\
PWT7 & South Purwokerto, Banyumas District & 7.4243 S 109.2396 E & 1 & MT881573 \\
PWT6 & South Purwokerto, Banyumas District & 7.4243 S 109.2396 E & 1 & MT881574 \\
PWT5 & South Purwokerto, Banyumas District & 7.4243 S 109.2396 E & 1 & MT881575 \\
PWT4 & South Purwokerto, Banyumas District & 7.4243 S 109.2396 E & 1 & MT881576 \\
PWT3 & South Purwokerto, Banyumas District & 7.4243 S 109.2396 E & 1 & MT881577 \\
PWT2 & South Purwokerto, Banyumas District & 7.4243 S 109.2396 E & 1 & MT881578 \\
PWT1 & South Purwokerto, Banyumas District & 7.4243 S 109.2396 E & 1 & MT881579 \\
PWT1 & South Purwokerto, Banyumas District & 7.4243 S 109.2396 E & 1 & MT881580 \\
CGK10 & South Purwokerto, Banyumas District & 7.4243 S 109.2396 E & 1 & MT881581 \\
CGK9 & South Purwokerto, Banyumas District & 7.4243 S 109.2396 E & 1 & MT881582 \\
CGK8 & South Purwokerto, Banyumas District & 7.4243 S 109.2396 E & 1 & MT881583 \\
CGK7 & South Purwokerto, Banyumas District & 7.4243 S 109.2396 E & 1 & MT881584 \\
CGK6 & South Purwokerto, Banyumas District & 7.4243 S 109.2396 E & 1 & MT881585 \\
CGK5 & South Purwokerto, Banyumas District & 7.4243 S 109.2396 E & 1 & MT881586 \\
CGK4 & South Purwokerto, Banyumas District & 7.4243 S 109.2396 E & 1 & MT881587 \\
CGK3 & South Purwokerto, Banyumas District & 7.4243 S 109.2396 E & 1 & MT881588 \\
CGK2 & South Purwokerto, Banyumas District & 7.4243 S 109.2396 E & 1 & MT881589 \\
CGK1 & South Purwokerto, Banyumas District & 7.4243 S 109.2396 E & 1 & MT881590 \\
\hline
\end{tabular}




\section{RESULTS AND DISCUSSION}

\section{Haplotype distribution}

A total of 20 sequences were generated, 10 from each population (South Purwokerto and Cilongok). The length of the sequences after alignment was around 600 bp. A total of 10 haplotypes and 9 polymorphic sites were identified (Table 2). The haplotypes were distinguished by 7 transitions $\mathrm{A} \Leftrightarrow \mathrm{G}$ or $\mathrm{G} \Leftrightarrow \mathrm{A}$ at positions $(9,147,159,303$, 309,593 and 594), single $\mathrm{C} \Leftrightarrow \mathrm{T}$ transition at position 45 , and 1 single $\mathrm{T} \Leftrightarrow \mathrm{A}$ transversion at position 525 . The Haplotype $\mathrm{H} 1$ and $\mathrm{H} 3$ were found in both populations, while the H2, H4, H5, H6, and $\mathrm{H} 7$ were unique to South Purwokerto samples, and $\mathrm{H} 8$, and $\mathrm{H} 10$ were exclusive to the population of Cilongok (Table 3).

\section{Polymorphism indices}

The overall number of haplotypes (h) was 10 , haplotype diversity $(\mathrm{Hd})$ was 0.921 , the average number of nucleotide differences $(\mathrm{k})$ was 2.552 and nucleotide diversity $(\pi)$ was 0.004. South Purwokerto samples had higher values, which are as follows: $\mathrm{h}=7, \mathrm{Hd}=0.933, \mathrm{~S}=8, \mathrm{~K}=2.933$ and $\pi=$ 0.005 (Table 4).

\section{Neutrality test}

Tajima D values for South Purwokerto and Cilongok were $(0.084)$ and (0.093), respectively with $p>0.05$, while $\mathrm{Fu}$ values were (0.506) and (1.340), respectively with $p>0.02$ (Table 4). Positive non-significant values indicating the observed polymorphism were consistent with the neutral mutation model.

\section{Mismatch distribution}

According to the significant values of Raggedness index R and SSD for South Purwokerto and Cilongok samples (Table 5), demographic expansion would be rejected. In contrast, the values of R Index and SSD were non-significant and good fit for the spatial expansion model $(\mathrm{SSD}=0.046, p=0.310$ and $\mathrm{R}=0.162, p=0.170)$ for South Purwokerto and (SDD $=0.063, p=0.0330$ and $\mathrm{R}=$ $0.211, p=0.340$ ) for Cilongok. Longer expansion time and migration rate were observed in the South Purwokerto samples $\tau(95 \%$ C.I $)=11.813$ and M $(95 \%$.C.I $)=152.881)$ implying long distant spatial expansion for older lineage. The Cilongok samples had shorter expansion time and smaller migration rate $\tau(95 \%$ C.I $)=7.527$ and $\mathrm{M}(95 \%$ C.I $=49.910$ ).

\section{AMOVA analysis}

AMOVA results showed greater variation $(82.15 \%)$ within the population and lower variation $(17.85 \%)$ among population $(p<0.02)$ (Table 6). The population pairwise

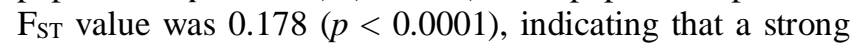
genetic structuring occurred in the sampled population of Ae. aegypti.

\section{Haplotype network}

The Median-Joining haplotype network showed that the haplotypes were interconnected with more than one nucleotide substitution. Haplotypes represented in red color were generated from South Purwokerto, and the ones in yellow color are for Cilongok haplotypes (Figure 2). H1 and $\mathrm{H} 3$ were shared between both populations. The highest mutation number was eight, and it was found between $\mathrm{H} 1$ and H10, and there were 4 steps between $\mathrm{H} 4$ and H10. South Purwokerto haplotypes were separated by a higher number of mutations, while Cilongok haplotypes were closely related and separated by fewer number of mutations.

\section{Phylogenetic analysis}

Neighbor-Joining (NJ) phylogenetic tree indicated that the haplotypes were clustered into a single clade supported by bootstrapping values $65 \%(\mathrm{H} 3, \mathrm{H} 8, \mathrm{H} 9$, and $\mathrm{H} 10), 58 \%$ (H1, H2, H5, H6, H7, and H9), and 56\% (H4) (Figure 3). $\mathrm{H} 1$ and $\mathrm{H} 2$ were similar to Ae. aegypti isolate from Semarang (KT313650 and KX1713940); H3 and H5 to H10 were close to haplotypes from Semarang (KP334268.1 and KP334269.1) and Panama and Pacific region. H4 was located in root of phylogenetic tree suggesting oldest haplotype in the area. The majority of haplotypes generated in this study were of similar origin compared to Ae. aegypti isolate of Semarang.

Table 2. Polymorphic sites in 10 haplotypes obtained from 603 bp fragment of Ae. aegypti specimens

\begin{tabular}{|c|c|c|c|c|c|c|c|c|c|c|}
\hline \multirow{4}{*}{ Haplotypes } & \multicolumn{10}{|c|}{ Polymorphic sites } \\
\hline & 9 & 4 & 1 & 1 & 3 & 3 & 5 & 5 & 5 & \\
\hline & & 5 & 4 & 5 & $\mathbf{0}$ & $\mathbf{0}$ & 2 & 9 & 9 & \\
\hline & & & 7 & 9 & 3 & 9 & 5 & 3 & 4 & $\mathbf{N}^{\mathrm{a}}$ \\
\hline H1 & $\mathrm{A}$ & $\mathrm{C}$ & G & A & $\mathrm{A}$ & A & $\mathrm{T}$ & A & G & 3 \\
\hline $\mathrm{H} 2$ & . & $\mathrm{T}$ & . & . & . & . & . & . & . & 1 \\
\hline H3 & . & . & . & 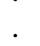 & $\mathrm{G}$ & . & . & 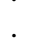 & . & 4 \\
\hline $\mathrm{H} 4$ & . & . & . & G & . & 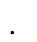 & $\mathrm{A}$ & G & . & 2 \\
\hline H5 & 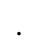 & . & $\mathrm{A}$ & . & . & G & . & . & & 2 \\
\hline H6 & $\mathrm{G}$ & . & . & . & . & G & . & G & . & 1 \\
\hline $\mathrm{H} 7$ & $\mathrm{G}$ & . & $\mathrm{A}$ & . & . & $\mathrm{G}$ & . & . & & 1 \\
\hline H8 & . & . & . & . & $\mathrm{G}$ & . & . & . & A & 1 \\
\hline H9 & $\mathrm{G}$ & . & . &. & $\mathrm{G}$ & . & . & $\mathrm{G}$ & . & 2 \\
\hline $\mathrm{H} 10$ & . & . & . & & $\mathrm{G}$ & & . & G & & 3 \\
\hline
\end{tabular}

Note: $\mathrm{N}^{\mathrm{a}}=$ the number of individuals in each haplotype

Table 3. Haplotype distribution for Ae. aegypti samples in South Purwokerto and Cilongok, Banyumas District, Central Java, Indonesia

\begin{tabular}{lccc}
\hline \multirow{2}{*}{ Haplotypes } & $\begin{array}{c}\text { South } \\
\text { Purwokerto }\end{array}$ & Cilongok & Total \\
\cline { 2 - 4 } & & 1 & $\mathbf{N}^{\mathbf{a}}$ \\
\hline H_1 & 2 & 0 & 3 \\
H_2 & 1 & 3 & 1 \\
H_3 & 1 & 0 & 4 \\
H_4 & 2 & 0 & 2 \\
H_5 & 2 & 0 & 2 \\
H_6 & 1 & 0 & 1 \\
H_7 & 1 & 1 & 1 \\
H_8 & 0 & 2 & 1 \\
H_9 & 0 & 3 & 2 \\
H_10 & 0 & 10 & 3 \\
Total & 10 & 20 \\
\hline
\end{tabular}

Note: $\mathrm{N}^{\mathrm{a}}=$ the number of individual in each haplotype 
Table 4. Genetic variability indices for the Ae. aegypti samples from South Purwokerto and Cilongok, Banyumas District, Central Java, Indonesia

\begin{tabular}{lllllllllll}
\hline Population & $\mathbf{N}$ & $\mathbf{H}$ & $\mathbf{H d}$ & $\mathbf{k}$ & $\boldsymbol{\pi}$ & $\mathbf{S}$ & Tajima D & $\boldsymbol{p}$-value & Fs & $\boldsymbol{p}$-value \\
\hline South Purwokerto & 10 & 7 & 0.933 & 2.933 & 0.005 & 8 & 0.084 & 0.555 & 0.506 \\
Cilongok & 10 & 5 & 0.844 & 1.311 & 0.002 & 4 & 0.093 & 0.570 & 1.340 & 0.764 \\
Total estimate & 20 & 10 & 0.921 & 2.552 & 0.004 & 9 & & & & \\
\hline
\end{tabular}

Note: N: number of sequences; H: number of haplotypes; Hd: haplotype diversity; S: number of segregating sites; K: average number of differences, $\pi$ : nucleotide diversity, D: Tajima statistics and Fs: Fu's neutrality test

Table 5. Estimates of the demographic and spatial expansion model, sum of squared deviation (SSD) and Harpending's raggedness index $(R)$

\begin{tabular}{llllllll}
\hline Demographic expansion & Tau CI 95\% & Theta0 CI95\% & Theta1 CI95\% & SSD & SDD $p$-value & R index & R $p$-value \\
\hline South Purwokerto & 13.908 & 5.218 & 165.099 & 0.049 & 0.040 & 0.162 & 0.040 \\
Cilongok & 7.431 & 2.046 & 325.156 & 0.081 & 0.020 & 0.211 & 0.040 \\
Spatial expansion & Tau CI 95\% & Theta CI95\% & M CI95\% & SSD & SSD $p$-value & R index & R $p$-value \\
South Purwokerto & 11.813 & 4.366 & 152.881 & 0.046 & 0.310 & 0.162 & 0.170 \\
Cilongok & 7.527 & 1.735 & 49.910 & 0.063 & 0.330 & 0.211 & 0.340 \\
\hline
\end{tabular}

Note: Tau: expansion time, (Theta 0 and 1; initial and final mutation, M: rate of migration, and CI: confidence Interval

Table 6. Analysis of Molecular Variance (AMOVA) for Cytochrome Oxidase I (COI) of Ae. aegypti samples from South Purwokerto and Cilongok Banyumas District, Central Java, Indonesia

\begin{tabular}{lcccc}
\hline Source of variation & d.f. & $\begin{array}{c}\text { Variance } \\
\text { components }\end{array}$ & $\begin{array}{c}\text { Variation } \\
(\boldsymbol{\%})\end{array}$ & p-value \\
\hline Among populations & 1 & $0.712 \mathrm{Va}$ & 17.85 & 0.00196 \\
Within populations & 18 & $3.277 \mathrm{Vb}$ & 82.15 & \\
Total & 19 & 69.400 & 3.990 & \\
\hline
\end{tabular}

Note: d.f: degree of freedom. The obtained FST value was 0.178; p-value : $0.00000+-0.0000$

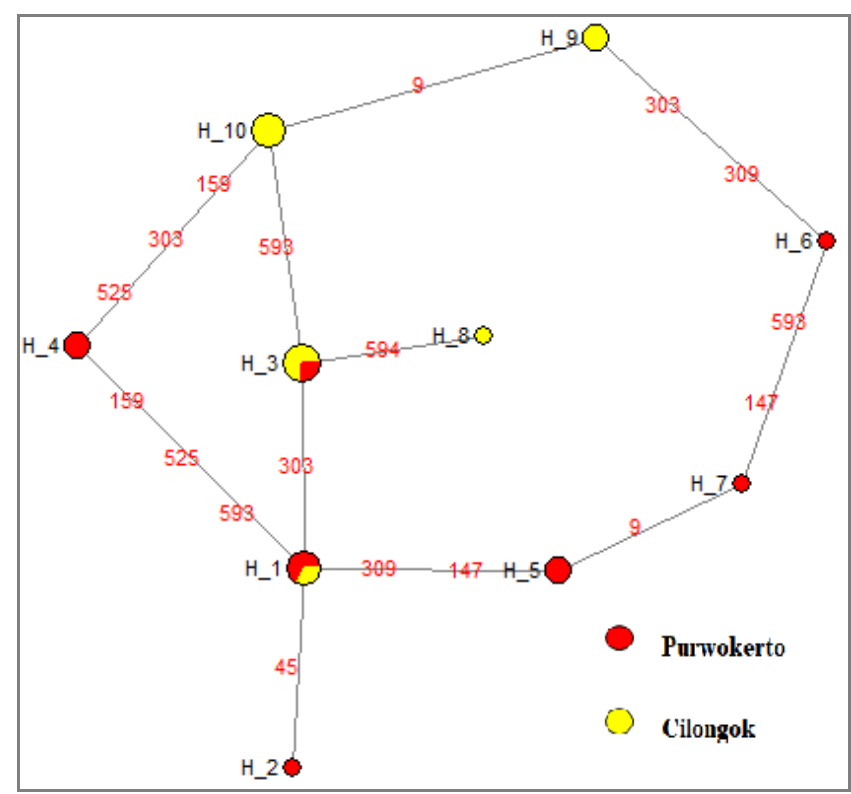

Figure 2. Haplotype network of cytochrome oxidase I of the Ae. aegypti. The nodes represent the proportion of individuals in each haplotype, each line in the network represents a single mutation, and numbers are position of mutation between two haplotypes

\section{Discussion}

Analysis of $600 \mathrm{bp}$ fragments of Cytochrome oxidase-I revealed a significant level of polymorphism among $20 \mathrm{Ae}$. aegypti samples generating 10 haplotypes, $\mathrm{H} 1$, and $\mathrm{H} 3$ were found in both locations. The majority of haplotypes fell into South Purwokerto samples (H1 to $\mathrm{H} 7)$, while in Cilongok (H3 and $\mathrm{H} 8$ to $\mathrm{H} 10)$. The indices of genetic diversity, haplotype diversity Hd and nucleotide diversity $\pi$ were relatively higher in South Purwokerto $(\mathrm{Hd}=0.933 ; \pi$ $=0.005)$ than Cilongok $(\mathrm{Hd}=0.844 ; \pi=0.002)$. These differences could be attributed to difference in physical environment and the variability of mosquito breeding sites which influence the species genetic diversity (Nei et al. 1975). Insecticides used for vector control are quite often conducted in urban settings, which can reduce population size and induces bottleneck and genetic drift effects (Urdaneta-Marquez and Anna-Bella 2011). In general, low genetic diversity could mostly result from a decline in population size (Marcombe et al. 2013). However, some studies have revealed high genetic diversity of Ae. aegypti population in areas with frequently use insecticides (Paupy et al. 2000). In this study, the sampled population did not undergo genetic bottleneck assuming the control measures had little impact on reducing mosquito populations. High haplotype diversity and low nucleotide diversity found in this study may indicate expansion after a period of low population size followed by population growth which enhances the evolution of new mutations (Avise et al. 1984). The nucleotide diversity recorded in this study is slightly similar to those recorded in previous studies, for example in North Coast of Central Java: $\pi \sim 0.00099$ and 0.0122 (Yohan et al. 2018). In addition to those reported worldwide i.e., Africa: $\pi=0.013$ (Bennett et al. 2016), Brazil: $\pi=0.00748$ (Fraga et al. 2013), Bolivia: $\pi=$ 0.00135 (Paupy et al. 2012), Colombia: $\pi=0.001$ to 0.008 (Jaimes-Dueñez et al. 2015) and Malaysia: $\pi=0.002$ to 0.03 (Naim et al. 2020). 


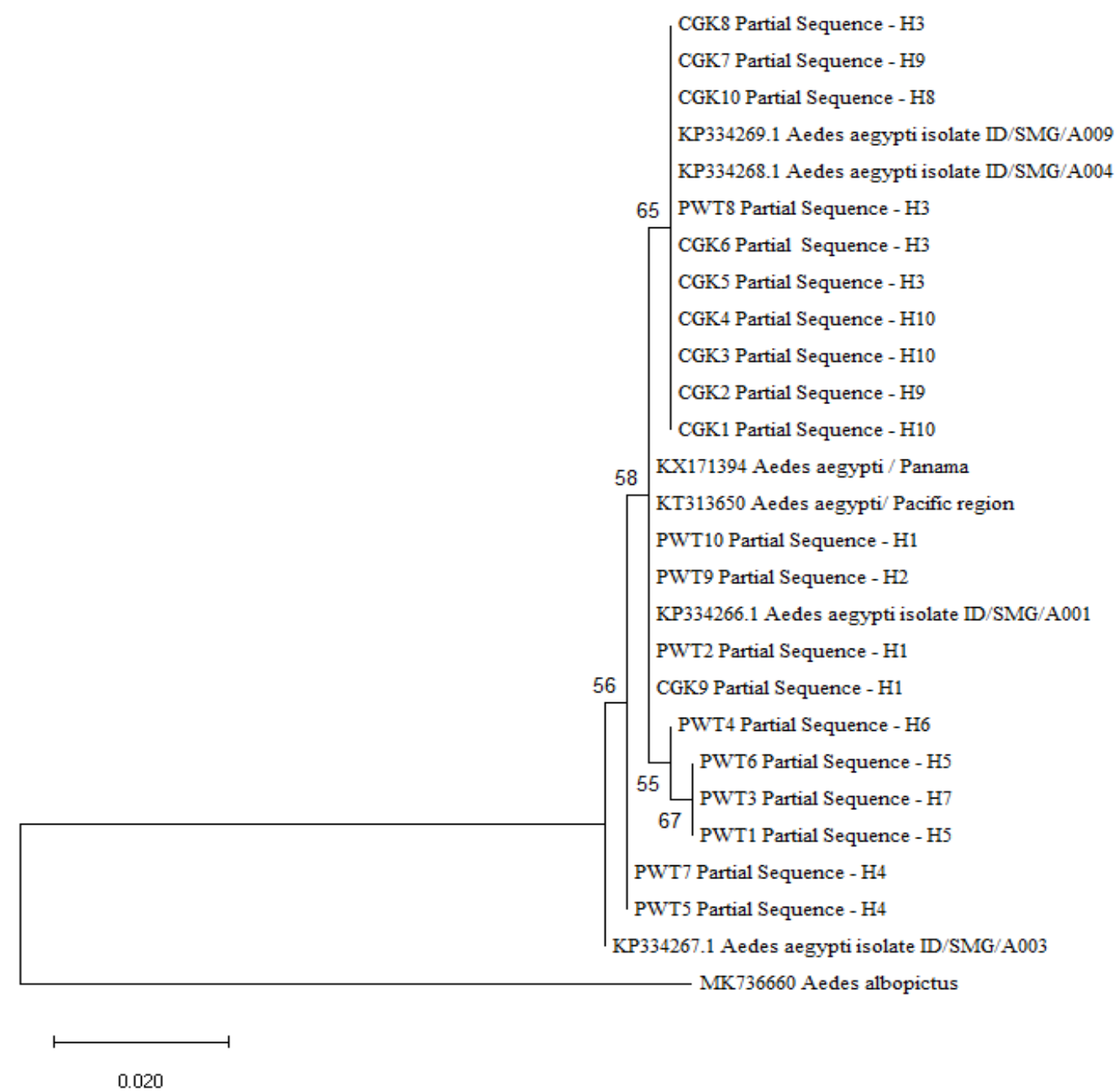

Figure 3. Neighbor-joining (NJ) tree for forward sequences of Ae .aegypti CO-I from South Purwokerto (PWT), Cilongok (CGK) of Banyumas District, Central Java, Indonesia, and sequence retrieved from GenBank. using 1000 bootstrap replication

Tajima $D$ statistics and Fu's value were positive nonsignificant $(\mathrm{P}>0.05)$ in both populations (Table 4$)$; the positive Tajima $D$ may indicate that the populations are in genetic equilibrium and balancing selection (Brito et al. 2002). Fu's test (Fu 1997) is more sensitive for population expansion and more powerful to measure population growth than Tajima test (Tajima 1989). Positive nonsignificant Fu's may indicate alleles deficiency as a result of over-dominant selection or recent population bottleneck (Fu 1997; Liao et al. 2010).

Mismatch distributions for demographic and spatial expansions showed multimodal distribution, suggesting that the populations were under demographic equilibrium. The indices of SSD and raggedness index $R$ were significant $(p<0.05)$. This implies there is a deviation from the demographic expansion model assuming that the populations were under demographic equilibrium. In contrast, the analysis failed to reject the spatial expansion model for both populations due to non-significant values of $S S D$ and $R(p>0.05)$ assuming that the sampled populations underwent spatial expansion. Moreover, different expansion times $(\tau)$ and rates of migration $(M)$ were observed (Table 5). South Purwokerto samples have had far distant spatial expansion from their older lineage when compared to the recent expansion showed in Cilongok samples (Harpending 1994; Excoffier 2004). From these findings, the demographic history of Ae. aegypti is consistent with the hypothesis of past spatial expansion (Liao et al. 2010). Additionally, the phylogenetic tree revealed South Purwokerto haplotypes were older than recently derived haplotypes in Cilongok. A previous report (Rašić et al. 2015) indicated that human transportation; environmental factors could facilitate the expansion of $A e$. aegypti, however, this suggestion is not fully understood within the context of the current study; the optimum temperature, humidity, and abundance of breeding sites are factors that may sustain adaptation and expansion of $A e$. aegypti to this region (Seixas et al. 2019).

The AMOVA analysis was used to test genetic differentiation in which populations were grouped into South Purwokerto and Cilongok. The analysis revealed that the genetic variation within the population was $(82.15 \%)$ 
and among the population was (17.85\%), and this is significant $(p<0.02)$. Likewise, the value of population pairwise $\mathrm{F}_{\mathrm{ST}}(0.178 \%)$ was highly significant $(p<0.0001)$ indicating that great genetic differentiation occurred between the sampled populations. In this study, moderate gene flow has occurred between the two populations $(\mathrm{H} 1$ and H3). A combination of factors such as rainwater and rivers, close distance between the two sites $(15 \mathrm{~km})$, connection by pathways, and people movement might have contributed to dispersal of the mosquitoes (Lima Jr \& Scarpassa 2009; Nazri et al. 2013). This is assuming that these factors andand physical environment and other human activities may influence the genetic structure of $A e$. aegypti (Huber et al. 2002; Guagliardo et al. 2014).

The haplotype network revealed that South Purwokerto samples had a higher number of haplotypes and mutations, although, South Purwokerto is capital city of Banyumas; population density around 234,400 peoples and urbanized compared to suburb in Cilongok (Central Bureau of Statistics 2011), the physical environment could offer diverse range of mosquito breeding sites thus eventually affect the structure of Ae. aegypti population (Huber et al. 2002; Nazri et al. 2013). High haplotype events could be correlated with insecticides for vector control, which is a potential factor associated with the evolution of new mutations ( $\mathrm{Li}$ et al. 2012). Limited haplotypes and mutations were found in Cilongok, in which the mosquito collection was performed at a hilly and elevated site of 143 $\mathrm{m}$ above sea level, which suggests that inbreeding effects may result in weak genetic diversity, as observed in Cilongok (Chakraborty et al. 1992). The H1 and H3 were found in the population of South Purwokerto and Cilongok assuming common ancestral haplotypes in this region and due to evidence of gene flow between the two populations. Haplotype sharing commonly resulted from extensive gene flow and migration between distant populations (Naim et al. 2020).

The phylogenetic tree indicated clustering of the haplotypes into a single clade (Figure 3), Additionally, the unrooted haplotype network supports one lineage's assumption, as well as previous studies, have reported a single clade in Central Java (Yohan et al. 2018). The H3, $\mathrm{H} 8, \mathrm{H} 9$, and $\mathrm{H} 10$ were closely related to previously isolated Ae. aegypti from Semarang city in Indonesia (KP334268.1, and KP334269.1). Semarang is a major harbor connecting different Regencies inside and out of Central Java. Presumably, through human transport, mosquitoes' stages are dispersed in Central Java areas (Huber et al. 2004; da Silva et al. 2012). The H4, located at the root of the phylogenetic tree, forming a separate subgroup. The $\mathrm{H} 1$ and $\mathrm{H} 2$ were more similar to haplotypes from Panama (KX171394) and the pacific region (KT313650) and Semarang (KP334266.1), indicating that same isolate of Ae. aegypti. Previously, different studies revealed that Ae. aegypti samples from Southeast Asia (Vietnam and Indonesia), the Pacific region (French Guiana), and South America (Bolivia and Mexico) were shared a similar ancestor (Failloux et al. 2002; Gorrochotegui-Escalante et al. 2002; Paupy et al. 2012; Yohan et al. 2018).
In conclusion, this study indicates that the COI marker is a powerful tool for assessing the genetic differentiation and gene flow in Ae. aegypti population in South Purwokerto and Cilongok of Banyumas District, Indonesia. A moderate level of gene flow found between the two populations may allow insecticide-resistant genes to spread throughout the gene flow.

\section{ACKNOWLEDGEMENTS}

This study was supported by Universitas Jenderal Soedirman, Banyumas, Indonesia research grant 2018. The authors acknowledge the people who have supported this work especially in Cilongok, Banyumas District, Indonesia.

\section{REFERENCES}

Anoopkumar AN, Puthur S, Rebello S, Aneesh EM. 2019. Molecular characterization of Aedes, Culex, Anopheles, and Armigeres vector mosquitoes inferred by mitochondrial cytochrome oxidase 1 gene sequence analysis. Biologia 74: 1125-1138. DOI: 10.2478/s11756019-00231-0

Avise JC, Neigel JE, Arnold J. 1984. Demographic influences on mitochondrial DNA lineage survivorship in animal populations. J Mol Evol 20: 99-105. DOI: 10.1007/BF02257369

Banyumas District Government Health Office, Central Java. 2020. Dengue fever often makes trouble, Banyumas District Dengue fever alert. https: //jateng.antaranews.com/berita/274860/demam-berdarahsering-bikin-repot-pemkab-banyumas-siaga-dbd. [Indonesian]

Beebe NW, Whelan PI, van-den Hurk A, Ritchie S, Cooper RD. 2005. Genetic diversity of the dengue vector Aedes aegypti in Australia and implications for future surveillance and mainland incursion monitoring. Commun Dis Intell Q Rep 29 (3): 299-304.

Bennett KL, Shija F, Linton YM, Misinzo G, Kaddumukasa M, Djouaka R, Anyaele O, Harris A, Irish S, Hlaing T, Prakash A. 2016. Historical environmental change in Africa drives divergence and admixture of Aedes aegypti mosquitoes: A precursor to successful worldwide colonization. Mol Ecol 25 (17): 4337-4354. DOI: 10.1111/mec.13762

Black IV WC, Bennett KE, Gorrochótegui-Escalante N, Barillas-Mury CV, Fernández-Salas I, Muñoz ML, Farfán-Alé JA, Olson KE, Beaty BJ. 2002. Flavivirus susceptibility in Aedes aegypti: A review. Arch Med Res 33: 379-388. DOI: 10.1016/s0188-4409(02)00373-9.

Borst P. 2005. Ethidium DNA agarose gel electrophoresis; how to start. IUBMB Life 57: 745-747. DOI: 10.1080/15216540500380855.

Brady OJ, Gething PW, Bhatt S, Messina JP, Brownstein JS, Hoen AG, Moyes CL, Farlow AW, Scott TW, Hay SI. 2012. Refining the global spatial limits of dengue virus transmission by evidence-based consensus. PLoS Negl Trop Dis 6: e1760. DOI: 10.1371/journal.pntd.0001760.

Brito RA, Manfrin MH, Sene FM. 2002. Mitochondrial DNA phylogeography of Brazilian populations of Drosophila buzzatii. Gen Mol Biol 25: 161-171.

Chakraborty R, Jin L.1992. Heterozygote deficiency, population substructure and their implications in DNA fingerprinting. Hum Genet 88: $267-72$.

Central Bureau of Statistics. 2011. Banyumas District in Figures 2011. Banyumas Central Bureau of Statistics, Banyumas.

Central Bureau of Statistics. 2017. Banyumas District in Figures 2017. Banyumas Central Bureau of Statistics, Banyumas.

da Silva AG, Cunha I, Santos W, Luz S, Ribolla P, Abad-Franch F. 2012. Gene flow networks among American Aedes aegypti populations. Evol Appl 5 (7): 664-676. DOI: 10.1111/j.1752-4571.2012.00244.x

Excoffier L, Lischer HEL. 2010. Arlequin suite ver 3.5: A new series of programs to perform population genetics analyses under Linux and Windows. Mol Ecol Res 10 (3): 564-567. DOI: 10.1111/j.17550998.2010.02847.x

Excoffier L. 2004. Patterns of DNA sequence diversity and genetic structure after a range expansion: Lessons from the infinite-island 
model. Mol Ecol 13 (4): 853-864. DOI: 10.1046/j.1365294x.2003.02004.x

Excoffier L, Smouse PE, Quattro JM. 1992. Analysis of molecular variance inferred from metric distances among DNA haplotypes: Application to human mitochondrial DNA restriction data. Genetics 131: 479-49.

Fay RW, Perry AS. 1965. Laboratory studies of ovipositional preferences of Aedes aegypti. Mosq News 25: 276-281.

Fraga EC, Oliveira DR, Aragão DG, Schneider H, Sampaio I. 2013. Genetic variability and evidence of two distinct lineages of Aedes aegypti (Diptera, Culicidae) on São Luís Island in Maranhão, Brazil. Brazil Open Trop Med J 6: 11-18.

Fu YX. 1997. Statistical tests of neutrality of mutations against population growth, hitchhiking and background selection. Genetics 147: 915925.

Gandhi R, Yadav KK, Patil PB, Bihani P, Char B, Dasgupta SK, Zehr UB, Barwale SR. 2020. Molecular analysis of mitochondrial cytochrome oxidase 1 gene of Aedes aegypti L. mosquitoes. J Asia Pac Entomol 23: $51-59$

Gorrochotegui-Escalante N, Gomez-Machorro C, Lozano-Fuentes S, Fernandez-Salas L, De Lourdes Munoz M, Farfan-Ale JA, GarciaRejon J, Beaty BJ, Black 4th WC. 2002. Breeding structure of Aedes aegypti populations in Mexico varies by region. Am J Trop Med Hyg 66 (2): 213-222. DOI: 10.4269/ajtmh.2002.66.213

Götz T, Altmeier N, Bock W, Rockenfeller R, Wijaya KP. 2017.Modeling dengue data from Semarang, Indonesia. Ecol Complex 30: 57-62.

Guagliardo SA, Barboza JL, Morrison AC, Astete H, Vazquez-Prokopec G, Kitron U. 2014. Patterns of geographic expansion of Aedes aegypti in the Peruvian Amazon. PLoS Negl Trop Dis 8: e3033. DOI: 10.1371/journal.pntd.0003033.

Hamilton G, Currat M, Ray N, Heckel G, Beaumont M, Excoffier L. 2005. Bayesian estimation of recent migration rates after a spatia expansion. Genetics 170: 40-417. DOI: 10.1534/genetics.104.034199

Harpending H. 1994. Signature of ancient population growth in a lowresolution mitochondrial DNA mismatch distribution. Hum Biol 66 : 591-600.

Huber K, Loan LL, Chantha N, Failloux AB. 2004. Human transportation influences Aedes aegypti gene flow in Southeast Asia. Acta Trop 90 (1): 23-29. DOI: 10.1016/j.actatropica.2003.09.012

Huber K, Le Loan L, Hoang TH, Ravel S, Rodhain F, Failloux AB. 2002. Genetic differentiation of the dengue vector, Aedes aegypti (Ho Chi Minh City, Vietnam) using microsatellite markers. Mol Ecol 11 (9): 1629-1635. DOI: 10.1046/j.1365-294x.2002.01555.x.

Jaimes-Dueñez J, Arboleda S, Triana-Chávez O, Gómez-Palacio A. 2015. Spatio-temporal distribution of Aedes aegypti (Diptera: Culicidae) mitochondrial lineages in cities with distinct dengue incidence rates suggest complex population dynamics of the dengue vector in Colombia. PLoS Negl Trop Dis 9 (4): e0003553. DOI: 10.1371/journal.pntd.0003553.

Kumar S, Stecher G, Li M, Knyaz C, Tamura K. 2018. MEGA X: Molecular Evolutionary Genetics Analysis across computing platforms. Mol Biol Evol 35 (6): 1547-1549. DOI: 10.1093/molbev/msy096

Kusmintarsih ES, Hayati RF, Turnip ON, Yohan B, Suryaningsih S, Pratiknyo H, Denis D, Sasmono RT. 2018. Molecular characterization of dengue viruses isolated from patients in Central Java, Indonesia. J Infect Public Health 11: 617-625.

Liao PC, Kuo DC, Lin CC, Ho KC, Lin TP, Hwang SY. 2010. Historical spatial range expansion and a very recent bottleneck of Cinnamoтиm kanehirae Hay. (Lauraceae) in Taiwan inferred from nuclear genes.BMC Evol 10: 124. DOI: 10.1186/1471-2148-10-124

Li T, Zhang L, Reid WR, Xu Q, Dong K, Liu N. 2012. Multiple mutations and mutation combinations in the sodium channel of permethrinresistant mosquitoes, Culex quinquefasciatus. Scientific Rep 2: 781. DOI: $10.1038 /$ srep00781

Lima Jr RS, Scarpassa VM. 2009. Evidence of two lineages of the dengue vector Aedes aegypti in the Brazilian Amazon, based on mitochondrial DNA ND4 gene sequences. Genetics and Molecular Biology 32 (2): 414-422. DOI: 10.1590/S1415-47572009005000036

Marcombe S, Paris M, Paupy C, Bringuier C, Yebakima A, Chandre F, David JP, Corbel V, Despres L. 2013. Insecticide-driven patterns of genetic variation in the dengue vector Aedes aegypti in Martinique Island. PLoS One 8: e77857. DOI: 10.1371/journal.pone.0077857

Meteorological, Climatological, and Geographical Agency, Indonesia. 2020. Climate Data in Indonesia. https: //www.bmkg.go.id/
Moyes CL, Vontas J, Martins AJ, Ng LC, Koou SY, Dusfour I, Raghavendra K, Pinto J, Corbel V, David JP, Weetman D. 2017. Contemporary status of insecticide resistance in the major Aedes vectors of arboviruses infecting human. PLoS Negl Trop Dis 11: e0005625. DOI: 10.1371/journal.pntd.0005625.

Naim DM, Kamal NZ, Mahboob S. 2020. Population structure and genetic diversity of Aedes aegypti and Aedes albopictus in Penang as revealed by mitochondrial DNA cytochrome oxidase 1 . Saudi J Biol Sci 27: 953-967. DOI: $10.1016 /$ j.sjbs.2020.01.021

Nathan MB.1993. Critical review of Aedes aegypti control programs in the Caribbean and selected neighboring countries. J Am Mosq Control Assoc 9: 1-7.

Nei M, Maruyama T, Chakraborty R. 1975. The bottleneck effect and genetic variability in populations. Evol 29: 1-10.

Nazri CD, Abu Hassan A, Zulkiflee AL, Rodziah I, Biswajeet P. 2013. Coupling of remote sensing data and environmental-related parameters for dengue transmission risk assessment in Subang Jaya, Malaysia. Geocarto Intl 28: 258-272.

Paupy C, Le Goff G, Brengues C, Guerra M, Revollo J, Simon ZB, Hervé JP, Fontenille D. 2012. Genetic structure and phytogeography of Aedes aegypti, the dengue and yellow-fever mosquito vector in Bolivia. Infect Genet Evol 12 (6): 1260-9126. DOI: 10.1016/j.meegid.2012.04.012.

Paupy C, Vazeille-Falcoz M, Mousson L, Rodhain F, Failloux A. 2000. Aedes aegypti in Tahiti and Moorea (French Polynesia): Isoenzyme differentiation in the mosquito population according to human population density. Am J Trop Med Hyg 62 (2): 217-224. DOI: 10.4269/ajtmh.2000.62.217

Rasheed SB, Boots M, Frantz AC, Butlin RK. 2013. Population structure of the mosquito Aedes aegypti (Stegomyia aegypti) in Pakistan. Med Vet Entomol 27 (4): 430-440. DOI: 10.1111/mve.12001.

Rašić G, Endersby-Harshman N, Tantowijoyo W, Goundar A, White V, Yang Q, Filipović I, Johnson P, Hoffmann AA, Arguni E. 2015. Aedes aegypti has spatially structured and seasonally stable populations in Yogyakarta, Indonesia. Parasites and Vectors 8: e77857. DOI: 10.1186/s13071-015-1230-6.

Roger AR, Harpending H. 1992. Population growth makes waves in the distribution of pairwise genetic differences. Mol Biol Evol 9: 559569.

Rozas J, Ferrer-Mata A, Sanchez-delBarrio JC, Guirao-Rico S, Librado P, Romas-Onsins SE, Sanchez-Gracia. 2017. DnaSP v6: DNA polymorphism Analysis of Large Datasets. Mol Biol Evol 34 (12): 3299-3302. DOI: $10.1093 / \mathrm{molbev} / \mathrm{msx} 248$

Scarpassa VM, Cardoza TB, Cardoso Junior RP. 2008. Population genetics and phylogeography of Ae. aegypti (Diptera: Culicidae) from Brazil. Am J Trop Med Hyg 78: 895-903.

Seixas G, Salgueiro P, Bronzato-Badial A, Gonçalves Y, Reyes-Lugo M, Gordicho V, Ribolla P, Viveiros B, Silva AC, Pinto J, Sousa CA. 2019. Origin and expansion of the mosquito Aedes aegypti in Madera Island (Portugal). Sci Rep 19 (9): 2241. DOI: 10.1038/s41598-01838373-x.

Seixas G, Salgueiro P, Silva AC, Campos M, Spenassatto C, Reyes-Lugo, M, Novo MT, Ribolla PEM, Pinto JPSDS, Sousa CA. 2013. Aedes aegypti on Madeira Island (Portugal): genetic variation of a recently introduced dengue vector. Memórias do Instituto Oswaldo Cruz 108: 3-10.

Sharma AK, Chandel K, Tyagi V, Mendki MJ, Tikar SN, Sukumaran D. 2013. Molecular phylogeny and evolutionary relationship among four mosquitoes (Diptera: Culicidae) species from India using PCR-RFLP. J Mosq Res 8: 58-64. DOI: 10.5376/jmr.2013.03.0008.

Stojanovich CHS. 1965. Illustrated Key to Mosquitoes of Vietnam. U.S. Department of Health, Education and Welfare, Public Health Service, CDC Atlanta, Atlanta.

Tajima F. 1989. Statistical method for testing the neutral mutation hypothesis by DNA polymorphism. Genetics 123: 585-595.

Twerdochlib AL, Bonna AC, Leite SS, Chitolina RF, Westphal B, Navarro-Silva MA. 2012. Genetic variability of a population of Aedes aegypti from Paraná, Brazil, using the mitochondrial ND4 gene. Rev Bras Entomol 56: 249-56.

Urdaneta-Marquez L, Anna-Bella F. 2011. Population genetic structure of Ae. aegypti, the principal vector of dengue viruses. Infection, Genetics and Evolution 11 (2): 253-261. DOI: 10.1016/j.meegid.2010.11.020

Vontas J, Kioulos E, Pavlidi N, Morou E, Della Torre A, Ranson H. 2012. Insecticide resistance in the major dengue vectors Aedes albopictus 
and Aedes aegypti. Pestic Biochem Phys 104: 126-131. DOI: 10.1016/j.pestbp.2012.05.008

Wijayanti SP, Sunaryo S, Suprihatin S, McFarlane M, Rainey SM, Dietrich I, Schnettler E, Biek R, Kohl A. 2016. Dengue in Java, Indonesia: Relevance of mosquito indices as risk predictors. PLoS Negl Trop Dis 10: e0004500.

World Health Organization. 2019. Dengue and severe dengue [Fact sheet, Updated 15 April 2019]. https://www.who.int/news-room/factsheets/detail/dengue-and-severe-dengue; accessed on April 2019.
Yohan B, Fauziah Y, Sayono S, Trimarsanto H, Sasmono RT. 2018. Genetic diversity of Aedes aegypti (Diptera: Culicidae) isolated from five cities in north coast area of Central Java, Indonesia. SE Asian J Trop Med 49: 217-226.

Yoshikawa MJ, Kusriastuti R. 2013. Surge of dengue virus infection and chikungunya fever in Bali: The burden of mosquito-borne infectious diseases in a tourist destination. Trop Med Health 41 (2): 67-78. DOI: 10.2149/tmh.2011-05 